\title{
SISTEM INFORMASI KENAIKAN PANGKAT KARYAWAN PADA DINAS PEKERJAAN UMUM (PU) DAN ENERGI SUMBER DAYA MINERAL (ESDM) KABUPATEN LOMBOK TENGAH
}

\author{
Mahni Pitriyawati ${ }^{1}$, Khairul Imtihan ${ }^{2}$ \\ ${ }^{1}$ Teknik Informatika, STMIK Lombok \\ ${ }^{2}$ Sistem Informasi, STMIK Lombok \\ Jln. Basuki Rahmat No.105 Praya Lombok Tengah 83511 \\ ${ }^{1}$ mahnipitriyawati@yahoo.com, ${ }^{2}$ khairulimtihan31@gmail.com
}

\begin{abstract}
Along with the increasingly tight competition of technology and information, making many government parties in Indonesia use technology as a supporter to improve its performance. The development of information technology systems led to changes in the role of information technology systems ranging from the role of efficiency, effectiveness to the strategic role, the existence of computerized data processing information becomes very important. That's because computerized data processing can contribute greatly to a company's performance, when compared to manual data processing. (Imtihan, 2015)

Dinas Pekerjaan Umum (PU) dan Energi Sumber Daya Mineral (ESDM) Kota Praya Kabupaten Lombok Tengah do not have a computerized system for data processing promotion of employees, still done manually and data storage is still archive so as to enable the loss of damaged data or archive and also takes longer time in data processing employees. The process can create a continuous error and since the promotion is routinely given to the employee, it is necessary to create an information system that can manage the promotion process automatically in order to avoid mistakes or continuous errors such as errors when data lost or damaged archives and accelerate in time processing data employee who will conduct the promotion process so that required a computerized promotion information system that can regulate the process of promotion of employees.

The information system is built using PHP programming language and Mysql database. Data collection method used in this research is the method of observation, interview, and literature study. The method of analysis used is SWOT method, design method used in this research is waterfall method and testing method used is black box testing method. The result of this research is to produce information system of processing process of promotion of employee to facilitate the employee in search process of promotion data and can facilitate officer at the time of data processing increase of employee pangat and also to minimize mistake of data processing promotion of employee rank.
\end{abstract}

Keywords : Information System, Promotion, PHP, MySql.

\begin{abstract}
Abstrak
Seiring dengan semakin ketatnya persaingan teknologi dan informasi, membuat banyak para pihak pemerintahan di Indonesia memanfaatkan teknologi sebagai pendukung untuk meningkatkan kinerjanya. Perkembangan dari sistem teknologi informasi menyebabkan perubahan-perubahan peran dari sistem teknologi informasi yaitu mulai dari peran efisiensi, efektifitas sampai ke peran strategis, keberadaan pengolahan data informasi secara terkomputerisasi menjadi sangat penting. Hal itu dikarenakan pengolahan data secara terkomputerisasi dapat memberikan kontribusi yang besar untuk kinerja sebuah perusahaan, jika dibandingkan pengolahan data secara manual. (Imtihan, 2015)

Dinas Pekerjaan Umum (PU) dan Energi Sumber Daya Mineral (ESDM) Kota Praya Kabupaten Lombok Tengah belum memiliki sistem terkomputerisasi untuk pengolahan data kenaikan pangkat karyawannya, masih dilakukan secara manual dan penyimpanan datanya juga masih bersifat arsip sehingga memungkinkan terjadinya kehilangan data atau arsip rusak dan juga membutuhkan waktu yang lebih lama dalam pengolahan data pegawainya. Proses tersebut dapat membuat suatu kekeliruan yang
\end{abstract}


berkesinambungan dan karena kenaikan pangkat tersebut rutin diberikan kepada pegawai, maka perlu dibuat sistem informasi yang dapat mengatur proses kenaikan pangkat ini secara otomatis demi menghindari kekeliruan atau kesalahan yang berkelanjutan seperti kesalahan saat data hilang atau arsip rusak serta mempercepat dalam waktu pengolahan data pegawai yang akan melakukan proses kenaikan pangkat sehingga diperlukan sistem informasi kenaikan pangkat yang terkomputerisasi yang dapat mengatur proses kenaikan pangkat karyawan.

Sistem informasi dibangun dengan menggunakan bahasa pemrograman PHP dan database Mysql. Metode pengumpulan data yang digunakan pada penelitian ini adalah metode observasi, wawancara, dan studi pustaka. Metode analisis yang digunakan adalah metode SWOT, metode perancangan yang digunakan dalam penelitian ini adalah metode waterfall serta metode testing yang digunakan adalah metode testing black box. Hasil dari penelitian ini adalah menghasilkan sistem informasi pengolahan proses kenaikan pangkat pegawai untuk mempermudah pegawai dalam proses pencarian data kenaikan pangkat dan dapat mempermudah petugas pada waktu pengolahan data kenaikan pangat pegawai serta dapat meminimalisir kesalahan pengolahan data kenaikan pangkat pegawai.

Kata kunci : Sistem Informasi, Kenaikan Pangkat, PHP, MySql. 


\section{Pendahuluan}

Seiring dengan semakin ketatnya persaingan teknologi dan informasi, membuat banyak pihak pemerintahan di Indonesia memanfaatkan teknologi sebagai pendukung untuk meningkatkan kinerjanya. Perkembangan dari sistem teknologi informasi menyebabkan perubahan-perubahan peran dari sistem teknologi informasi yaitu mulai dari peran efisiensi, efektifitas sampai ke peran strategis, keberadaan pengolahan data informasi secara terkomputerisasi menjadi sangat penting. Hal itu dikarenakan pengolahan data secara terkomputerisasi dapat memberikan kontribusi yang besar untuk kinerja sebuah perusahaan. Jika dibandingkan pengolahan data secara manual, pengolahan data secara terkomputerisasi memiliki beberapa kelebihan, seperti : pengolahan data yang cepat dan akurat, serta mendukung pengolahan data dalam skala besar. (Imtihan, 2015)

Dinas Pekerjaan Umum (PU) dan Energi Sumber Daya Mineral (ESDM) Kota Praya Kabupaten Lombok Tengah belum memiliki sistem terkomputerisasi untuk pengolahan data kenaikan pangkat karyawannya, masih dilakukan secara manual, dan penyimpanan datanya juga masih bersifat arsip sehingga memungkinkan terjadinya kehilangan data atau arsip rusak dan juga membutuhkan waktu yang lebih lama dalam pengolahan data pegawainya. Proses tersebut dapat membuat suatu kekeliruan yang berkesinambungan dan karena kenaikan pangkat tersebut rutin diberikan kepada pegawai, maka perlu dibuat sistem informasi yang dapat mengatur proses kenaikan pangkat ini secara otomatis demi menghindari kekeliruan atau kesalahan yang berkelanjutan seperti kesalahan saat data hilang atau arsip rusak serta mempercepat dalam waktu pengolahan data pegawai yang akan melakukan proses kenaikan pangkat.

Dengan merancang suatu sistem informasi diharapkan akan dapat mengurangi kesalahankesalahan yang bisa terjadi, membantu proses yang telah ada serta dapat mempermudah kegiatan pengolahan data pegawai serta informasi yang berkaitan dengan kenaikan pangkat pegawai.

\section{Tinjuan Pustaka}

Junaidi, (2015), kualitas pelayanan kenaikan pangkat pegawai negeri sipil oleh badan kepegawaian daerah kabupaten gunung mas membahas mengenai pelaksanaan kenaikan pangkat penelitian ini diarahkan pada permasalahan Pelayanan Kenaikan Pangkat pegawai negeri sipil yang diberikan oleh badan kepegawaian daerah kabupaten gunung mas pada lingkungan pemerintah daerah kabupaten gunung mas khususnya kepada pegawai negeri sipil struktural yang mengusulkan kenaikan pangkat pada periode 1 april 2014.

Prabowo, dkk, (2015), perancangan sistem informasi surat referendum usulan kenaikan pangkat atau jabatan berbasis web. Perancangan penelitian menggunakan Pengembangan perangkat lunak yang dilakukan mengikuti metodologi FAST (Framework for Application Sistem Technologies) dan melaksanakan tahapan pengembangan mulai dari tahap scope definition, problem analysis, requirement analysis, logical design, decission analysis, physical design and integration, construction and testing, tanpa melakukan tahapan installation and delivery pada sistem nyata. Pengembangan perangkat lunak atau akan menggunakan bahasa script HTML, PHP, CSS, dan javascript. HTML untuk memberikan struktur bagi halaman web, PHP untuk logika program dan interaksi dengan basisdata, CSS untuk memperbaiki penampilan halaman web, dan javascript yang menangani validasi input dan interaktivitas halaman web.

Kusnadi. dkk, (2015) penerapan metode profile matching untuk penilaian kenaikan jabatan karyawan (Studi Kasus: PT. Ilham Bangun Mandiri). Pada penelitian ini akan diangkat suatu kasus yaitu mencari solusi terbaik bedasarkan kompetensi karyawan di PT. Ilham Bangun Mandiri menggunakan metode Profile matching. Metode ini dipilih karena mampu menyeleksi kandidat terbaik dari sejumlah karyawan yang ada, dalam hal ini kandidat yang dimaksudkan yaitu karyawan yang berhak menduduki jabatan yang tersedia berdasarkan kriteria-kriteria yang ditentukan. Penelitian dilakukan dengan mencari nilai bobot untuk setiap atribut, seperti contoh adalah aspek kapasitas intelektual, aspek sikap kerja, dan aspek perilaku, kemudian dilakukan proses perankingan yang akan menentukan alternatif yang optimal, yaitu karyawan terbaik.

Agusten, (2015), menjelaskan tentang prototype sistem informasi kenaikan pangkat pegawai negeri sipil studi kasus direktorat kepangkatan dan mutasi bkn jakarta. Penelitian ini bertujuan untuk membuat prototype yang berisi informasi tentang kenaikan pangkat pegawai negeri sipil di lingkungan Direktorat Kepangkatan dan Mutasi BKN Jakarta dengan berbasis website. Pengembangan sistem 
informasi ini dengan menggunakan aplikasi PHP MySQL, adobe dreamwever CS5, adobe photoshop CS3. Penelitian ini menggunakan metodologi pengembangan sistem informasi prototype yaitu metode pengembangan yang diawali dengan perencanaan dengan memfokuskan pada user dan menghasilkan prototype pada perancangan sebelum diimplementasikan dalam sistem yang besar. Hasil dari penelitian ini adalah sebuah prototype sistem informasi berbasis website tentang kenaikan pangkat pegawai negeri sipil untuk seluruh instansi pemerintahan di Indonesia. Prototipe sistem informasi kenaikan pangkat pegawai negeri sipil ini berhasil dibuat dan dijalankan pada instansi pemerintah di lingkungan Direktorat Kepangkatan dan Mutasi BKN Jakarta.

Septiana, (2012), membahas tentang Faktor-faktor Penghambat Kenaikan Pangkat Pejabat Fungsional Analis Kepegawaian pada Badan Kepegawaian Negara (BKN) Pusat. Penelitian ini merupakan penelitian kualitatif, dengan desain deskriptif, cross sectional, serta dilakukan dengan teknik wawancara mendalam dan studi kepustakaan. Hasil penelitian adalah terdapat 4 faktor yang menghambat kenaikan pangkat para analis kepegawaian di lingkungan BKN Pusat, yaitu penempatan yang tidak sesuai dengan formasi, kompetensi dan kreativitas pegawai yang kurang memadai, persyaratan pengusulan kenaikan pangkat yang tidak didukung oleh organisasi, serta minimnya rotasi pegawai.

\section{Metodologi Penelitian}

\subsection{Metode Pengumpulan Data}

1. Observasi

Teknik pengumpulan data yang dilakukan dengan cara mengadakan pengamatan secara langsung pada Dinas Pekerjaan Umum (PU) dan Energi Sumber Daya Mineral (ESDM) pada bagian kepegawaian.

\section{Wawancara}

Teknik pengumpulan data yang dilakukan dengan cara melakukan wawancara secara langsung kepada narasumber atau karyawan yang ada pada Dinas Pekerjaan Umum (PU) dan Energi Sumber Daya Mineral (ESDM) bagian kepegawaian.

\section{Studi Pustaka}

Mempelajari teori-teori baik dari buku-buku, jurnal dan internet yang berhubungan dengan tema penelitian.

\subsection{Metode Analisis}

Metode analisis yang digunakan dalam penelitian ini adalah metode SWOT dengan menganalisa kekuatan, kelemahan, peluang, dan ancaman sistem yang sedang berjalan.

\subsection{Metode Perancangan}

Metode Perancangan yang di gunakan dalam penelitian ini adalah Metode waterfall. Model waterfall mengelompokkan kegitan dalam fase-fase tahapan yaitu Perencanaan, analisis, perancangan, implemetasi, pengujian dan perawatan.

\subsection{Metode Pengujian Sistem}

Pada Penelitian penulis menggunakan metode testing black box yang dimana metode testing black box ini merupakan pengujian untuk mengetahui apakah semua fungsi perangkat lunak telah berjalan semestinya sesuai dengan kebutuhan fungsional yang telah didefinsikan.

\section{Hasil dan Pembahasan}

\subsection{Flowmap Sistem}

\subsubsection{Flowmap Sistem Berjalan}

Dari hasil analisis dapat diuraikan sistem yang sedang berjalan pada Dinas Pekerjaan Umum (PU) dan Energi Sumber Daya Mineral (ESDM) Kabupaten Lombok Tengah yaitu dengan dijelaskan pada flowmap 4.1 sistem yang sedang berjalan

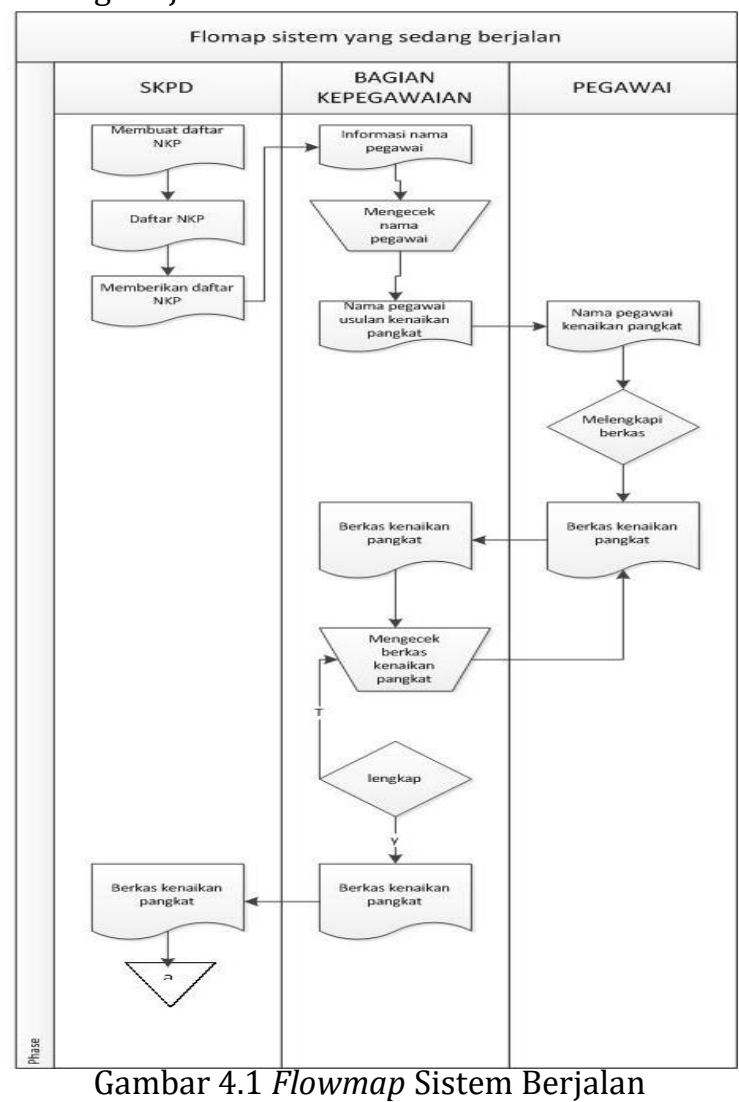


Keterangan Gambar :

1. SKPD membuat atau menyusun daftar nominatif kenaikan pangkat pegawai

2. SKPD memberikan daftar nominatif kenaikan pangkat pegawai kepada kasubag kepegawaian

3. Kasubag kepegawaian menyampaikan kepada masing-masing pegawai untuk melengkapi berkas usul kenaikan pangkat.

4. Pegawai melengkapi berkas usul kenaikan pangkat dan kemudian menyerahkan ke kasubag kepegawaian.

5. Kasubag kepegawaian memeriksa berkas usul kenaikan pangkat pegawai.

6. Jika pegawai yang bersangkutan tidak memenuhi berkas usul kenaikan pangkat maka berkas akan di arsipkan.

7. Akan tetapi jika berkas usul kenaikan pangkat pegawai terpenuhi maka kasubag kepegawaian menyerahkan berkas pegawai kepada SKPD.

8. Kemudian SKPD memberikan berkas usul kenaikan pangkat ke BKD

\subsubsection{Flowmap Usulan}

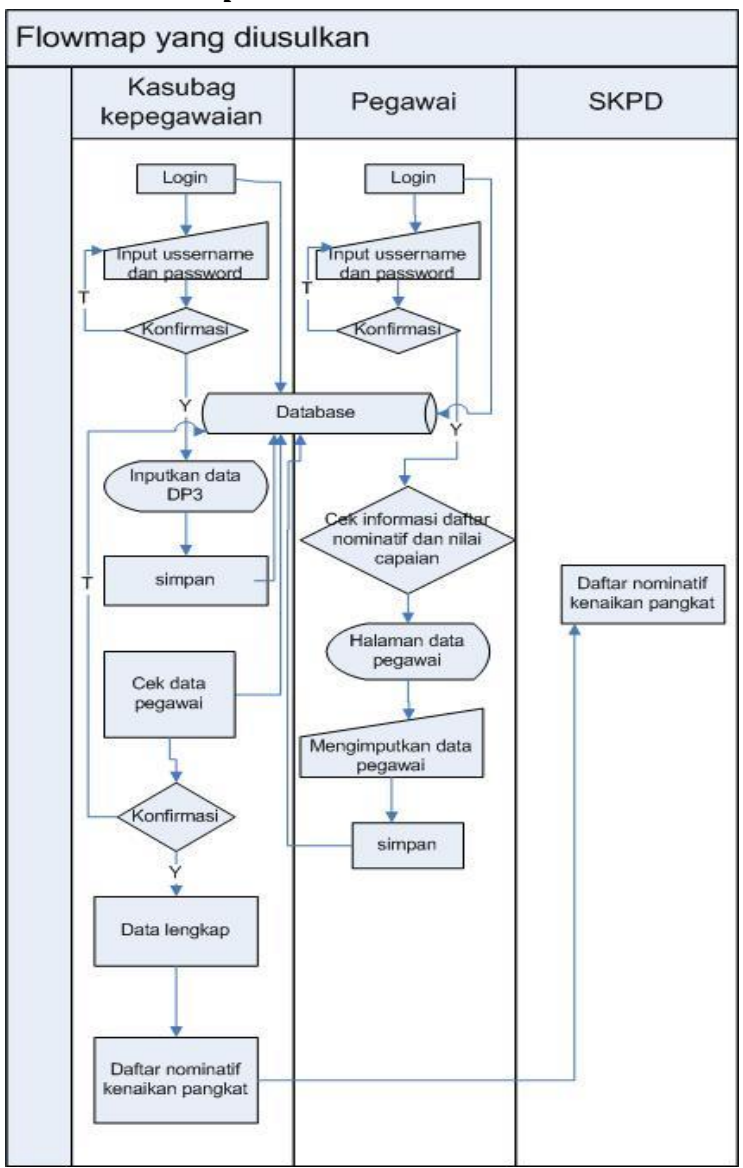

Gambar 4.2 Flowmap Usulan
Keterangan Gambar :

1. Kasubag kepegawaian melakukan proses login dengan menginputkan username dan password, jika username dan password benar maka kasubag kepegawaian berhasil masuk ke sistem, kemudian kasubag melakukan penginputan data DP3.

2. Proses selanjutnya pegawai melakukan proses login dengan memasukan username dan password. Jika username dan password benar maka pegawai berhasil masuk ke sistem, kemudian pegawai mengecek Daftar Nominatif dan nilai capaian SKP yang berasal dari data DP3 yang sudah di nilai oleh kasubag. Dan jika pegawai yang bersangkutan mencapai nilai capaian SKP maka nama pegawai tersebut terdaftar namanya di daftar nominatif dan kemudian melengkapi datanya atau syarat kenaikan pangkat (SK pangkat terakhir, SKP 2 Tahun terakhir DP3, daftar riwayat pekerjaan, Sk PNS, ijazah + transkip nilai, karpeg, nip baru).

3. Kasubag kepegawaian mengecek data pegawai yang sudah di lengkapi oleh pegawai yang bersangkutan atau pegawai yang sudah terdaftar di daftar nominatif kenaikan pangkat. Apa bila data pegawai belum lengkap maka kasubag menginformasikan kepada pegawai untuk melengkapi ulang datanya, tetapi jika data pegawai sudah lengkap maka kasubag mengirim daftar nominatif ke SKPD.

\subsection{Perancangan Proses}

\subsubsection{DFD (Data Flow Diagram)}

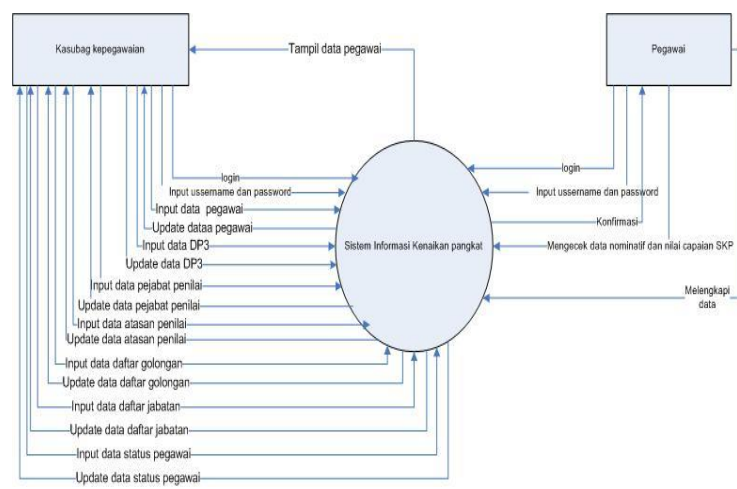

Gambar 4.3 Diagram Konteks Sistem Informasi Kenaikan Pangkat

Keterangan Gambar :

1. Kasubag kepegawaian login dengan menginputkan username dan password, jika username dan password benar maka bisa langsung masuk ke sistem dan kemudian kasubag juga bisa menginputkan beberapa data antara lain seperti data pegawai, data 
DP3, data pejabat penilai atau data kasubag sendiri, data atasan penilai, data daftar golongan, data daftar jabatan, dan data status pegawai.

2. Pegawai login dan menginputkan username dan password, jika username dan password benar maka pegawai bisa masuk ke sistem, kemudian pegawai bisa mengecek data nominatif dan nilai capaian SKP atau DP3, jika pegawai terdaftar namanya di dalam daftar nominatif maka pegawai bisa melengkapi datanya yang berupa berkas atau syarat usul kenaikan pangkat.

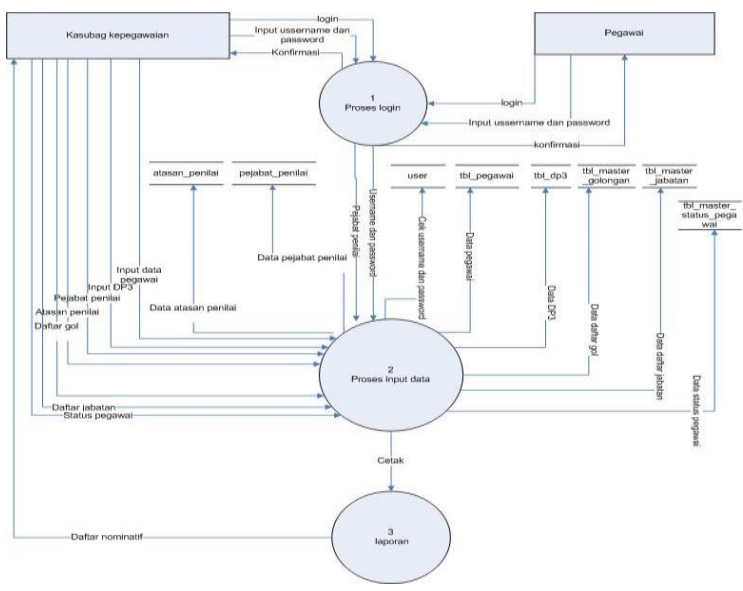

Gambar 4.4 DFD Level 1 Sistem Informasi Kenaikan Pangkat

Keterangan Gambar :

Alur dari sistem yang terdiri dari proses dimana kasubag kepegawaian login dengan menginputkan username dan password, jika username dan password benar maka bisa langsung masuk ke sistem dan kemudian kasubag juga bisa menginputkan beberapa data antara lain seperti data pegawai, data DP3, data pejabat penilai atau data kasubag sendiri, data atasan penilai, data daftar golongan, data daftar jabatan, dan data status pegawai.. Kasubag juga bisa mencetak daftar nominatif pegawai yang di usulkan untuk naik pangkat, yang di lihat dari hasil nilai capaian SKP atau DP3. Pegawai login dan menginputkan username dan password, jika username dan password benar maka pegawai bisa masuk ke system.

\subsubsection{Perancangan ERD (Entity Relationship Diagram)}

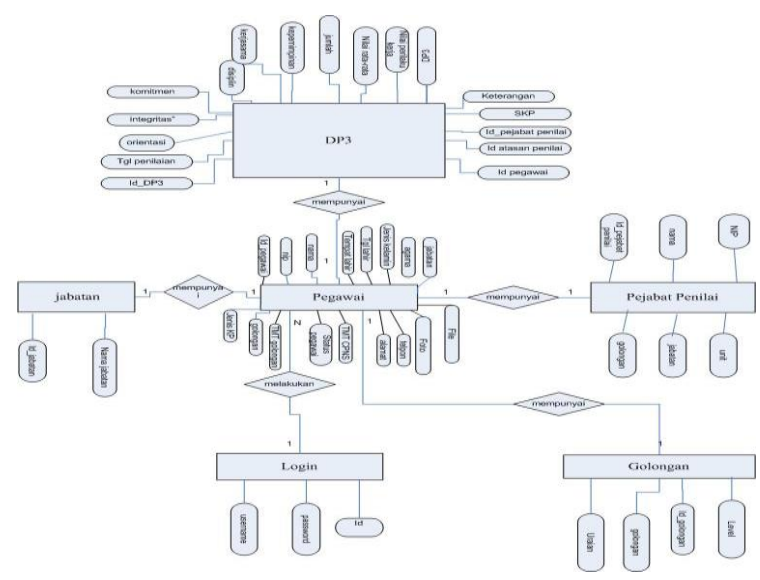

Gambar 4.5 ERD (Entity Relationship Diagram)

\subsubsection{Perancangan Struktur Menu}

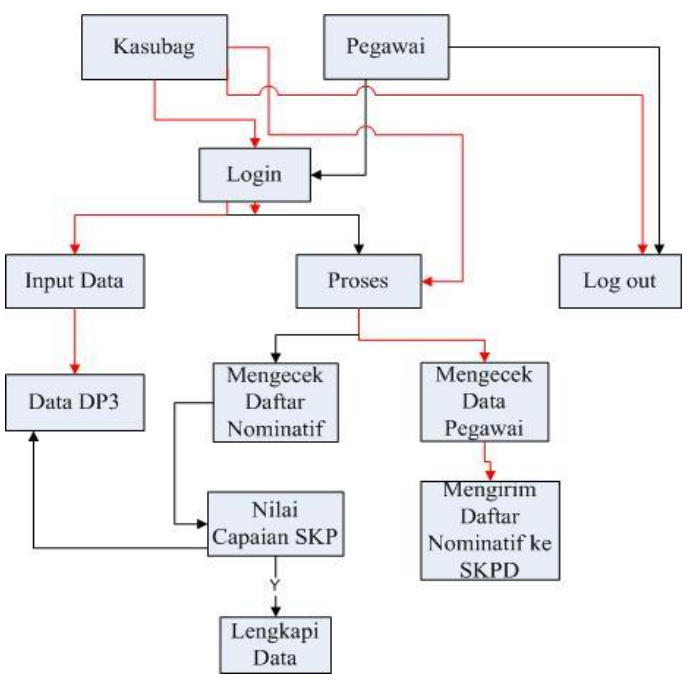

Gambar 4.6 Struktur Menu

\subsection{Perancangan Interface}

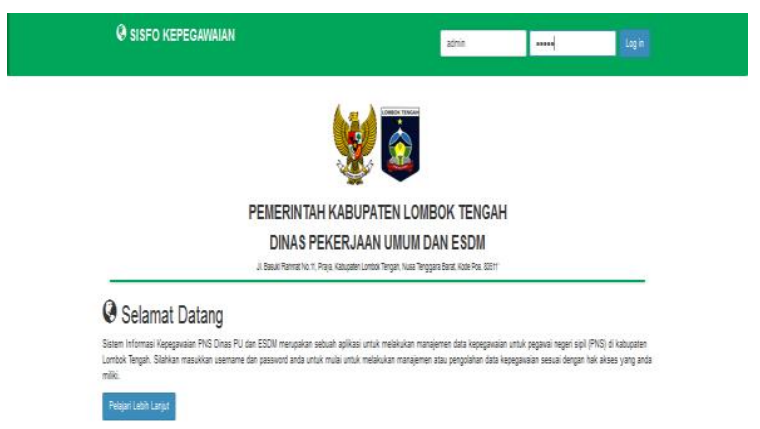


Menu login adalah halaman pertama sebelum user masuk kedalam sistem dan mengolah data, dalam menu login ini user diminta untuk menginputkan username dan password dengan benar pada form user dan password.

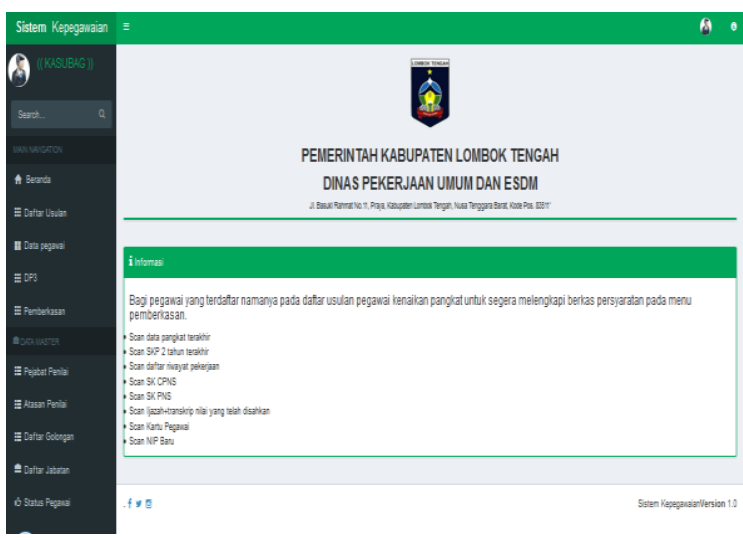

Gambar 4.8 Halaman Utama

Dalam konten beranda terdapat sebuah informasi bagi pegawai yang terdaftar namanya pada daftar usulan pegawai kenaikan pangkat untuk segera melengkapi berkas persyaratan pada menu pemberkasan. dan menu kelola data daftar usulan, data pegawai, data DP3, data pemberkasan, data pejabat penilai, data atasan penilai, data daftar golongan, data daftar jabatan, data status pegawai dan proses Log Out

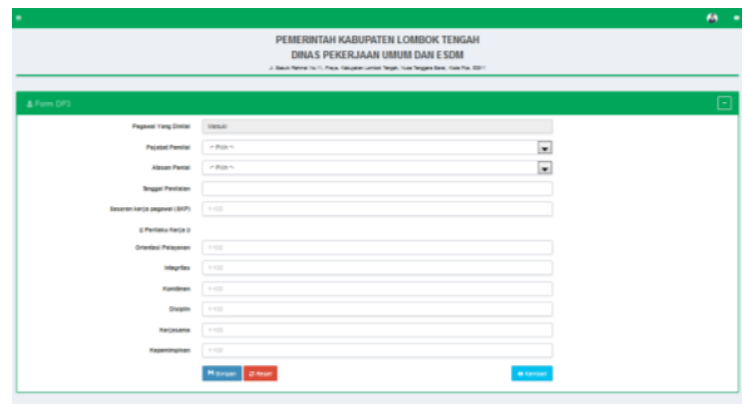

Gambar 4.9 Halaman Input DP3

DP3 yang dimana halaman ini merupakan tempat kasubag atau pejabat penilai melakukan penginputan nilai yang diberikan kepada masing-masing pegawai.

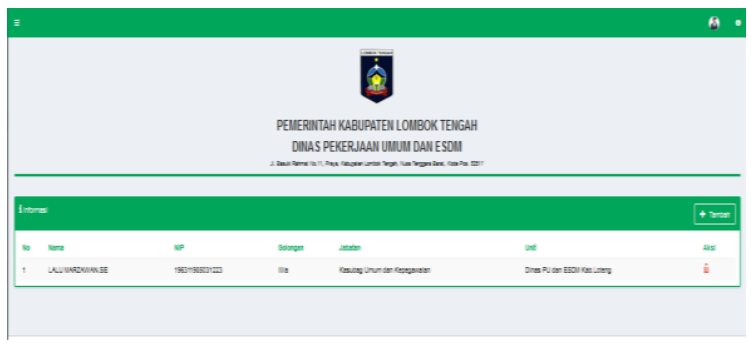

Keterangan Gambar :

halaman data pejabat penilai yang dimana pejabat penilai ini yang memberikan nilai kepada masing-masing pegawai. Pejabat penilai mempunyai atribut nama, nip, golongan, jabatan, unit

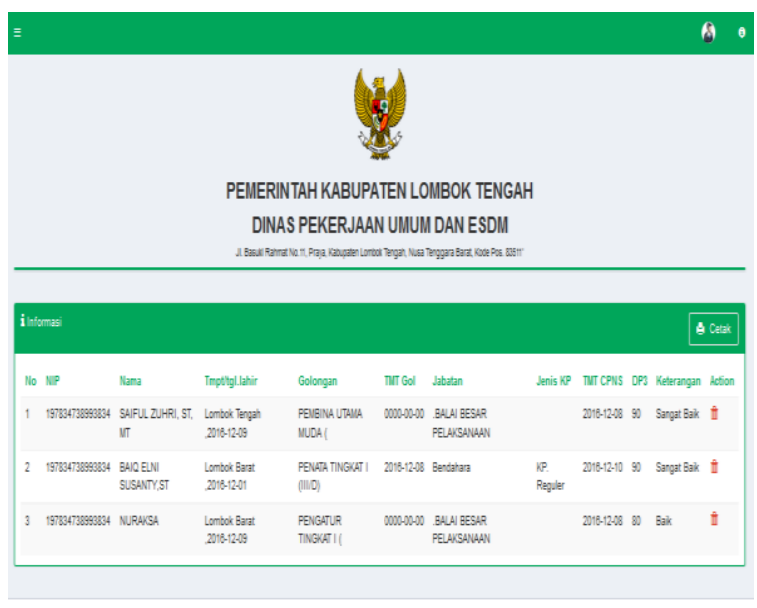

Gambar 4.11 Halaman Daftar Pengusul

\section{Kesimpulan dan saran}

\subsection{Kesimpulan}

Dari pembahasan mengenai Sistem Informasi Kenaikan Pangkat Karyawan Pada Dinas PU dan ESDM yang telah diuraikan maka penulis dapat menarik suatu kesimpulan sebagai berikut :

1. Dengan menggunakan sistem informasi kenaikan pangkat secara terkomputerisasi ini dapat mengefisiensi waktu maximal 30 menit setelah menggunakan sistem dibandingkan dengan proses sebelumya pada saat dilakukan secara manual yaitu minimal 2 hari.

2. Dengan menggunakan sistem informasi kenaikan pangkat atau sistem yang terkomputerisasi maka tidak perlu memerlukan tempat penyimpanan data yang besar, hanya disimpan didalam komputer kasubag saja, tidak seperti pada saat masih dilakukan penyimpanan yang bersifat arsip, memerlukan tempat yang besar, seperti lemari berukuran 3 meter $\mathrm{x} 2$ meter.

\subsection{Saran}

Untuk penelitian selanjutnya bisa dikembangkan dari segi tampilan programnya, sehingga masih diperlukan pengembangan-pengembangan lebih lanjut agar sistem informasi kenaikan pangkat karyawan yang dilakukan secara terkomputerisasi ini menjadi semakin lebih baik

Gambar 4.10 Halaman Pejabat Penilai 


\section{Daftar Pustaka:}

Abdulloh, Rohi, (2015). Web Programming Is Easy. Jakarta: Gramedia

Adi Nugroho, (2011). Perancanga Dan Implementasi Sistem Basis Data. Yogyakarta: Andi

Hanif Al Fatta, (2007). Analisi Dan Perancangan Informasi Untuk Keunggulan Bersaing Perusahaan Dan Organisasi Modern. Yogyakarta : Andi

Kadir, Abdul, (2009). Dasar perancangan \& implementasi Database Relasional. Yogyakarta : Andi

Kadir, Abdul, (2009).Pengenalan Sistem Informasi Jakarta : Andi

Komputer, Wahana. 2006. Panduan Praktis Pengolahan Database dengan MySQL. Yogyakarta: Andi

Madcoms, (2011). Aplikasi Web Database Dengan Dreamweaver dan PHP MySQL. Yogyakarta : Andi

Peranginangin, Kasiman (2006) Aplikasi WEB dengan PHP dan MySQL.Yogyakarta: Andi

Presman, S. Roger, (2010). Rekayasa Peranggkat Lunak-buku, Pendekatan Praktisi (Edisi 7). Yogyakarta : Andi

Siagian ,p.sondang (2002) System Informasi Manajemen Yogyakarta : Andi

Yakub, (2012). Pengantar Sistem Informasi. Yogyakarta: Andi

Agusten, dina, dkk, (2015) Prototype Sistem Informasi Kenaikan Pangkat Pegawai Negeri Sipil Studi Kasus Direktorat Kepangkatan Dan Mutasi BKN Jakarta. Jurnal digital informasi.
Junaidi, (2015) kualitas kenaikan pangkat pegawai negeri sipil oleh badan kepegawaian daerah kabupaten gunung mas. Pencerah publik. Vol. 2

Kusnadi, dkk (2015) penerapan metode profile matching untuk penilaian kenaikan jabatan kariawan (studi kasus:PT.ilham bangun mandiri). Jurnal digital. Vol 5

Prabowo, yudi, dkk, (2015) Perancangan Sistem Informasi Surat Referendum Usulan Kenaikan Pangkat Atau Jabatan Berbasis Web. Jurnal Teknologi Dan Sistem Komputer. Vol. 3

Septiana, (2012) faktor-faktor penghambat kenaikan pangkat pejabat fungsional analis kepegawaian pada badan kepegawaian negara (BKN) Pusat

Ahmad Susan Pardiansyah. "Audit Tata Kelola Teknologi Informasi Program Studi Sistem Informasi Sekolah Tinggi Manajemen Informatika Dan Komputer (STMIK) Lombok Menggunakan." IJSEIndonesian Journal on Software Engineering 1.1 (2015).

Maulana Ashari. "Audit Information Technology (IT) Governance Pada Sekolah Tinggi Manajemen Informatika Dan Komputer (STMIK) Lombok Menggunakan Framework COBIT 4.1." Bianglala Informatika 3.2 (2015).

Wire Bagye. "Analisis Tingkat Kematangan Sistem Informasi Akademik Menggunakan Framework COBIT 4.1 (Studi Kasus: STMIK Lombok)." SpeedSentra Penelitian Engineering dan Edukasi 8.1 (2016). 